\title{
創薬を目指す量子ビーム施設 一放射光と中性子の有効利用一
}

西島 和三, $*, a$ 清谷多美子 $b$

\section{Quantum Beam Facilities Aiming at Drug Discovery - Effective Use of Synchrotron Radiation and Neutron-}

\author{
Kazumi NishiJimA ${ }^{*, a}$ and Tamiko KIYOTANI ${ }^{b}$ \\ ${ }^{a}$ Mochida Pharmaceutical Co., Ltd., 1-22 Yotsuya, Shinjyuku-ku, Tokyo 160-0004, \\ Japan, and ${ }^{b}$ Showa Pharmaceutical University, 3-3165 Higashi-tamagawa
}

Gakuen, Machida, Tokyo 194-8543, Japan

わが国は，放射光及び中性子施設の研究・開発に おいて先駆であり，歴史的にも世界的にも現在に至 るまで高度な技術力を誇っており，国内外において 少なからず影響を与え，貢献してきた。

世界最高性能の第 3 世代大型放射光施設 SPring-8 (兵庫県西播磨) と草分け的存在である高エネルギー 加速器研究機構 (KEK) の Photon Factory (PF) （茨城県つくば市）は，教育機関及び研究機関，産 業において，基礎から応用まで種々の研究分野で利 用されているが，特に物質・生命科学分野への貢献 が顕著である。その放射光施設の有効利用によって 多大な成果を挙げた文部科学省の国家プロジェクト 「タンパク 3000 プロジェクト」に引き続く「ターゲ ットタンパク研究プログラム」では，創薬において 重要な疾患関連の膜タンパク質などがターゲットで あるが，その発現，精製，及び結晶化等が非常に困 難である。このような貴重な高難度タンパク質の結 晶解析を可能にするため，放射光施設の更なる高度 化を目指した研究及び技術開発が進行中である。 ま た，日本製薬工業協会（製薬協）のコンソーシアム (平成 21 年 4 月時点, 19 社加盟) は「タンパク 3000 プロジェクト」の恩恵を受けて専用ビームラ インを SPring-8 に保有し，その研究成果である標 的タンパク質の構造情報を有効利用した合理的な創 薬プロセスを実施している.

a持田製薬株式会社（干160-0004 東京都新宿区四谷 1$22), b$ 昭和薬科大学（干194-8543 東京都町田市東玉川 学園 3-3165)

*e-mail: kazumi@mochida.co.jp

日本薬学会第 129 年会シンポジウム S30 序文
一方，中性子施設では，日本原子力研究開発機構 （JAEA）（茨城県東海村）の研究用原子炉 JRR-3M において, 基礎研究から応用研究, 産業利用に至る まで多くの分野に利用され，社会に広く貢献してい る.さらに, 日本原子力研究開発機構と高エネル ギー加速器研究機構が共同で建設・運営を行う, 物 質・生命科学，原子核・素粒子物理，核変換技術等 への貢献が期待される大強度陽子加速器施設 $\mathrm{J}$ PARC（茨城県東海村）において，加速器を用いた 世界最高性能のパルス中性子・ミュオン実験施設 「物質・生命科学実験施設（MLF）」が 2008 年に完 成し，一部の先行ビームラインに関しては同年 12 月から運用が開始された。電荷を持たない中性子は 放射光とは異なる散乱によって，X 線では困難な 水素原子の観測を得意とし，水素・水和構造の解明 とともにタンパク質の機能解明に役立つと期待され る.その結果として，標的タンパク質の精密な構造 情報を有効利用した高精度な薬物設計が可能になる であろう。

このようなタイムリーな状況下に，わが国の量子 ビーム施設に係わる第一線の研究者が一堂に会して の創薬を目指した放射光と中性子の有効利用をテー マとしたシンポジウムを企画し，広く薬学分野の研 究者を対象として開催することは非常に有意義であ り，今後の更なる技術開発の進展とともに創薬への より一層の貢献が期待される.

以下に，本シンポジウムのシンポジスト及び講演 タイトルを講演順に紹介する.

〈放射光施設〉1.「ターゲットタンパク研究プログ ラムで目指す $\mathrm{X}$ 線構造解析の高度化」若槻壮市 
(高エネルギー加速器研究機構)，2．「放射光マイク ロビームが可能にするタンパク質微小結晶解析」山 本雅貴 (理化学研究所播磨研究所), 3.「SPring-8 構造生物ビームライン」熊坂 崇（高輝度光科学研 究センター)，〈中性子施設〉4.「中性子と放射光の
相補的な利用による創薬標的タンパク質の立体構造 解析」黒木良太（日本原子力研究開発機構），5. 「供用開始に際した J-PARC の新しい生物用中性子 回折装置 (iBIX)」田中伊知朗（茨城大学） 